\title{
Recovery of NIS expression in thyroid cancer cells by overexpression of Pax8 gene
} Ivan Presta ${ }^{1}$, Franco Arturi ${ }^{1}$, Elisabetta Ferretti ${ }^{2}$, Tiziana Mattei ${ }^{2}$, Daniela Scarpelli ${ }^{1}$, Emanuele Tosi ${ }^{2}$, Angela Scipioni ${ }^{2}$, Marilena Celano ${ }^{1}$, Alberto Gulino ${ }^{2,3}$, Sebastiano Filetti*2 and Diego Russo ${ }^{1}$

Address: ${ }^{1}$ Dipartimento di Medicina Sperimentale e Clinica "G. Salvatore" and Dipartimento di Scienze Farmacobiologiche, University of Catanzaro "Magna Graecia", Catanzaro, Italy, ${ }^{2}$ Dipartimento di Scienze Cliniche and Dipartimento di Medicina Sperimentale e Patologia, University of Rome "La Sapienza", Rome, Italy and ${ }^{3}$ Neuromed Institute, 86077 Pozzilli, Italy

Email: Ivan Presta - presta@unicz.it; Franco Arturi - arturi@unicz.it; Elisabetta Ferretti - eliferretti@tin.it;

Tiziana Mattei - tiziana.mattei@uniroma1.it; Daniela Scarpelli - dascar4@yahoo.it; Emanuele Tosi - emanuele.tosi@uniroma1.it; Angela Scipioni - angela.scipioni@tiscali.it; Marilena Celano - celano.donato@tiscali.it; Alberto Gulino - alberto.gulino@uniroma1.it; Sebastiano Filetti* - sebastiano.filetti@uniroma1.it; Diego Russo - d.russo@unicz.it

* Corresponding author

Published: 19 July 2005

BMC Cancer 2005, 5:80 doi:10.1 186/147/-2407-5-80
Received: 14 April 2005

Accepted: 19 July 2005

This article is available from: http://www.biomedcentral.com/I47/-2407/5/80

(c) 2005 Presta et al; licensee BioMed Central Ltd.

This is an Open Access article distributed under the terms of the Creative Commons Attribution License (http://creativecommons.org/licenses/by/2.0), which permits unrestricted use, distribution, and reproduction in any medium, provided the original work is properly cited.

\begin{abstract}
Background: Recovery of iodide uptake in thyroid cancer cells by means of obtaining the functional expression of the sodium/iodide symporter (NIS) represents an innovative strategy for the treatment of poorly differentiated thyroid cancer. However, the NIS gene expression alone is not always sufficient to restore radioiodine concentration ability in these tumour cells.
\end{abstract}

Methods: In this study, the anaplastic thyroid carcinoma ARO cells were stably transfected with a Pax8 gene expression vector. A quantitative RT-PCR was performed to assess the thyroid specific gene expression in selected clones. The presence of NIS protein was detected by Western blot and localized by immunofluorescence. A iodide uptake assay was also performed to verify the functional effect of NIS induction and differentiation switch.

Results: The clones overexpressing Pax 8 showed the re-activation of several thyroid specific genes including NIS, Pendrin, Thyroglobulin, TPO and TTFI. In ARO-Pax8 clones NIS protein was also localized both in cell cytoplasm and membrane. Thus, the ability to uptake the radioiodine was partially restored, associated to a high rate of efflux. In addition, ARO cells expressing Pax 8 presented a lower rate of cell growth.

Conclusion: These finding demonstrate that induction of Pax 8 expression may determine a redifferentiation of thyroid cancer cells, including a partial recovery of iodide uptake, fundamental requisite for a radioiodine-based therapeutic approach for thyroid tumours.

\section{Background}

Thyroid tumours show a good long-term survival, but, when we consider the poorly differentiated histotypes and in particular the anaplastic carcinoma, the prognosis is very poor $[1,2]$. A major determinant of such an opposite behaviour is the lost ability to concentrate the 
radioiodine, used as very effective tool for diagnosis and treatment for both tumour remnants or distant metastases [3]. The loss of iodide uptake capacity in poorly differentiated thyroid carcinomas is mainly due to the reduced/ lost functional expression of the sodium/iodide symporter (NIS), with a defect occurring mainly at gene expression level, but in some case involving post-transcriptional or other unknown alterations [4-7]. For this reason, many strategies have been used and are currently in progress in order to re-establish iodide uptake function by means of re-expressing the NIS in tumour cells. At present, two different strategies are based on: a. introducing NIS gene in cancer cells through a viral vector; b. stimulating endogenous NIS gene expression [5,7]. The latter approach may take advantage from the description and characterization of the human NIS gene promoter as well as studies regarding NIS expression regulation [4-7]. Among the physiological stimulators of NIS gene transcription, a pivotal role is played by the thyroid-specific transcription factor Pax8 [8-10]. This homeobox protein is able to regulate, in normal thyroid cells, the expression of many thyroid specific protein and is often reduced in thyroid tumours, especially in the less differentiated histotypes [11].

In this study we analysed the effects of Pax8 overexpression on a human thyroid anaplastic cancer cell line ARO cells. It is a widely used cell line which resembles the behaviour of poorly differentiated thyroid tumours, including a very low iodide uptake function as well as lost of NIS and Pax8 gene expression, together with several other markers of thyrocyte differentiation [12]. By restoring Pax8 expression, we observed the recovery of NIS expression, together with other markers of thyroid differentiation, associated to partial ability to uptake the radioiodine.

\section{Methods}

\section{Recombinant plasmid construction}

The plasmid vector pCMV and the full length CDNA fragment of Pax8 A (kindly provided by Dr. Di Lauro) [13], were cleaved by Kpn I and Eco RI. The cleaved products were ligated using T4DNA ligase into pCMV-Script cloning and expression vector (Stratagene, La Jolla, CA, USA). DH5 alpha cells were transformed using the recombinant product $\mathrm{pCMV} / \mathrm{Pax} 8$ and then screened for the positive clones containing the inserted fragment by colony-PCR techniques. The positive colonies were amplified, extracted, purified and identified by endonuclease cleavage. The sequences of the inserted fragments were confirmed by automated sequencing using ABI Prism 7700 Sequence Detector (Applied Biosystems, Foster City, CA, USA).

\section{Cell cultures and stable transfection}

ARO cells were cultured in RPMI 1640 medium with 10\% foetal bovine serum (Gibco, Milano, Italy) and containing penicillin/streptomycin and amphotericin B (SigmaAldrich S.r.l., Milano, Italy). The non-liposomal lipid mixture FUGENE 6 (Roche diagnostics, Monza, Italy) was used for transfection. ARO cells were plated at $3 \times 10^{5}$ cells/60 mm culture dish $24 \mathrm{~h}$ prior to transfection. $2 \mathrm{mg}$ of the construct and $2 \mu \mathrm{g}$ of empty vector in $200 \mu \mathrm{l}$ of serum free medium and $12 \mu$ of FUGENE 6 mixture each, were used for two different transfections. After $45 \mathrm{~min}$ of incubation at room temperature, the transfection mixture was added to the dishes with $2 \mathrm{ml}$ of fresh complete medium. The cells were grown for $24 \mathrm{~h}$ before adding 400 $\mu \mathrm{g} / \mathrm{ml}$ neomycin (Sigma-Aldrich S.r.l.) for selection and after 3 days the transfected cultures were split for single clone isolation. After propagation, total RNA was extracted from 24 isolated clones for screening of Pax8 gene expression by a quantitative RT-PCR. Cells transfected with the empty vector (ARO-pCMV) were used as control. FRTL-5 and CHO cells, used as additional control, were cultured as described previously [14].

\section{RNA extraction, reverse transcription and quantitative PCR}

Total RNA was extracted from cells with using the Qiagen RNA/DNA kit (Qiagen S.p.A, Milano, Italy), according to manufacturer's instructions. First-strand cDNA synthesis was performed using $2 \mu \mathrm{g}$ of each RNA sample primed with random hexamers with 200 U of Superscript II reverse transcriptase (Life Technologies S.r.l., San Giuliano milanese, Milano, Italy). Quantitative PCR analysis (Q-PCR) of Pax8, NIS, Thyroperoxidase (TPO), TSHReceptor (TSH-R), Thyroid transcription factor-1 (TTF1) and pendrin (PDS) mRNA expression was performed on cDNA samples employing the primers indicated in Table 1. Oligonucleotide primers and probe were purchased from Applied Biosystems as Assays-on-Demand Gene Expression Products for the study of Thyroglobulin (Tg), endogenous control glyceraldehyde-3-phosphate dehydrogenase (GAPDH) and $\beta$-actin were purchased from Applied Biosystems as TaqMan PDAR (VIC dye-labeled). A $25 \mu \mathrm{l}$ reaction mixture containing $2.5 \mu \mathrm{l}$ of cDNA template, $12.5 \mu \mathrm{l}$ TaqMan Universal PCR master mix (Applied Biosystems) and $1.25 \mu \mathrm{l}$ primer probe mixture was amplified using the following thermal cycler parameters: incubation at $50^{\circ} \mathrm{C}$ for $2 \mathrm{~min}$ and denaturing at $95^{\circ} \mathrm{C}$ for 10 min, then 40 cycles of the amplification step (denaturation at $95^{\circ} \mathrm{C}$ for $15 \mathrm{sec}$ and annealing/extension at $60^{\circ} \mathrm{C}$ for $1 \mathrm{~min}$ ). For each amplification run standard curve was generated using 6 serial dilutions of cDNA mix expressing all the genes analysed. All amplification reactions were performed in triplicate, and the averages of the threshold cycles were used to interpolate standard curves and to calculate the transcript amount in samples using SDS version 
Table I: Sequences of primer pairs and TaqMan probes

\begin{tabular}{|c|c|c|c|}
\hline Gene & Primer forward & Primer reverse & Probe \\
\hline Pax8 & 5'-CAACAGCACCCTGGACGAC-3' & 5'-AGGGTGAGTGAGGATCTGCC-3' & 5'-CTGACCCCTTCCAACACGCCACTG-3' \\
\hline NIS & 5'-CCATCCTGGATGACAACTTGG-3' & 5'-AAAAACAGACGATCCTCATTGGT-3' & 5'-AGAACTCCCCACTGGAAACAAGAAGCCC-3' \\
\hline TPO & 5'-ACGCCTCTGCGAGGTGC-3' & 5'-TGCAAATCACCGTCGAGGT-3' & 5'-TGCTGATCGGAGGCTTCGCAG-3' \\
\hline TSH-R & 5'-CCTTCACCTCACACGGGCT-3' & 5'-TGCTCTCATTACACATCAAGGACTC-3' & 5'-TTTCTTACCCAAGCCACTGCTGTGCC-3' \\
\hline TTF-I & 5'-CCTGTCCСАССТGAACTCСТC-3' & 5'-GCCTTTGTGGTTTTTTGTTCC-3' & 5'-CGGACTACGGCACCATGTCCTGC-3' \\
\hline Pendrin & 5'-CATCAAGACATATCTCAGTTGGACCT-3' & 5'-ACAGTTCCATTGCTGCTGGAT-3' & 5'-TCTGAGCATGGCCCCCGACG-3' \\
\hline
\end{tabular}

For Thyroglobulin gene were used primers and probes provided by Applied Biosystems (Assays-on-demand gene products).

1.7a software. Levels of mRNA expression were expressed after normalization with those of two endogenous controls, GAPDH and $\beta$-actin.

\section{Protein extraction, western blot analysis and immunofluorescence}

Total proteins were extracted from thyroid cell lines as described previously [15]. Briefly, confluent cells from 3 Petri dishes were collected and homogenized in $1 \mathrm{ml}$ of buffer containing $250 \mathrm{mM}$ sucrose, $10 \mathrm{mM}$ HEPES-KOH (pH 7.5), 1 mM EDTA, 1 mM PMSF, $10 \mu \mathrm{g} / \mathrm{ml}$ leupeptin, $10 \mu \mathrm{g} / \mathrm{ml}$ aprotinin (Sigma-Aldrich S.r.l.). The homogenate was centrifuged at $14000 \times \mathrm{g}\left(4^{\circ} \mathrm{C}\right.$ for $\left.15 \mathrm{~min}\right)$ and the supernatant (which contained the whole cell lysate) was quantified spectrophotometrically using the Bradford method. Twenty micrograms of proteins were loaded on a $4-20 \%$ gradient SDS-polyacrylamide gel and subjected to electrophoresis at a constant voltage $(110 \mathrm{~V})$. Electroblotting to a Hybond ECL-PVDF nitrocellulose membrane (Amersham Pharmacia biotech., Milano, Italy) was performed for $2 \mathrm{~h}$ at $125 \mathrm{~mA}$ using a Mini Trans blot electroblotting system (Bio-rad Laboratories S.r.l, Milano, Italy). Blocking was done using TTBS/milk (TBS, 1\% Tween 20, and $5 \%$ non fat dry milk) for $2 \mathrm{~h}$ at room temperature. The membrane was then incubated with a 1/500 dilution of affinity purified rabbit anti-NIS polyclonal antibody [16] or a $1 / 5000$ dilution of mouse monoclonal antihuman beta-actin antibody, overnight at $4^{\circ} \mathrm{C}$ in TTBS/ milk. After one $15 \mathrm{~min}$ and two $5 \mathrm{~min}$ washes in TTBS, the membrane was incubated with a 1/20000 dilution of a horse radish peroxidase conjugated anti-rabbit or antimouse antibody (Transduction Laboratories, Lexington, KY, USA) in TTBS/milk. After one $15 \mathrm{~min}$ and two $5 \mathrm{~min}$ washes in TTBS, the protein was visualized by an enhanced chemiluminescence Western blot detection system (ECL plus, Amersham Pharmacia biotech.).

For immunofluorescence analysis, the cells were plated on glass coverslips and fixed using PBS containing 4\% paraformaldehyde for $10 \mathrm{~min}$ at RT. Then the fixative was aspirated and the cells washed 3 times for 5 min each with
PBS. The cells were incubated with blocking buffer (PBS $1 \times+$ BSA $1 \%$ ) for $15 \mathrm{~min}$ at RT. Immunostaining was performed using 1:600 dilution of a rabbit polyclonal antibody anti h-NIS [15] for $1 \mathrm{~h}$ at RT. After three 5-min washes in PBS, the cells were incubated with secondary antibody conjugate with FITC (Sigma Aldrich S.r.l.) diluted 1:160 in PBS $1 \times$, for $30 \mathrm{~min}$ at RT, re-washed in PBS and incubated in Hoechst $1 \times$ for $3 \mathrm{~min}$ at RT. After three final PBS washes, the cells were mounted with Vectashield (Vector Laboratories, Inc. Burlingame, CA, USA).

\section{lodide uptake, efflux rate and cell growth rate assay}

Uptake of ${ }^{125}$ I was measured as previously described [17]. Briefly, cells were splitted and seeded into 12-well plates and, after aspirating the culture medium, washed with 1 $\mathrm{ml}$ of Hank's balanced salt solution (HBSS) (Life technologies S.r.l) supplemented with Hepes $10 \mathrm{mM}$, pH 7.3. ${ }^{125} \mathrm{I}$ uptake was initiated by adding to each well $500 \mu \mathrm{l}$ buffered HBSS containing $0.1 \mu \mathrm{Ci}$ carrier-free $\mathrm{Na}^{125} \mathrm{I}$ and 10 $\mu \mathrm{M} \mathrm{NaI}$ to obtain a specific activity of $20 \mathrm{mCi} / \mathrm{mmol}$.

In half of the wells, this assay buffer was supplemented with the NIS inhibitor $\mathrm{KClO}_{4}(10 \mu \mathrm{M})$ to control for specific uptake. After $40 \mathrm{~min}$ at $37^{\circ} \mathrm{C}$ in a humid atmosphere, the radioactive medium was aspirated and cells were washed with $1 \mathrm{ml}$ of ice-cold HBSS. One $\mathrm{ml}$ of 95\% ethanol was added to each well for $20 \mathrm{~min}$ and then transferred into vials for counting with a gamma counter. Iodide uptake was expressed as picomoles per $\mu \mathrm{g}$ of DNA. Each experiment was done at least twice in quadruplicates and the FRTL-5 cells and CHO cells were used, respectively, as positive and negative controls.

Iodide efflux in wild-type and transfected ARO cells, as well FRTL-5 cells, was evaluated as previously described by Arturi et al. [14].

For cell growth rate analysis, $10^{5}$ cells were plated in 60 $\mathrm{mm}$ dishes. Seven hours were considered as extra time needed from cells to sediment and start to proliferate. 


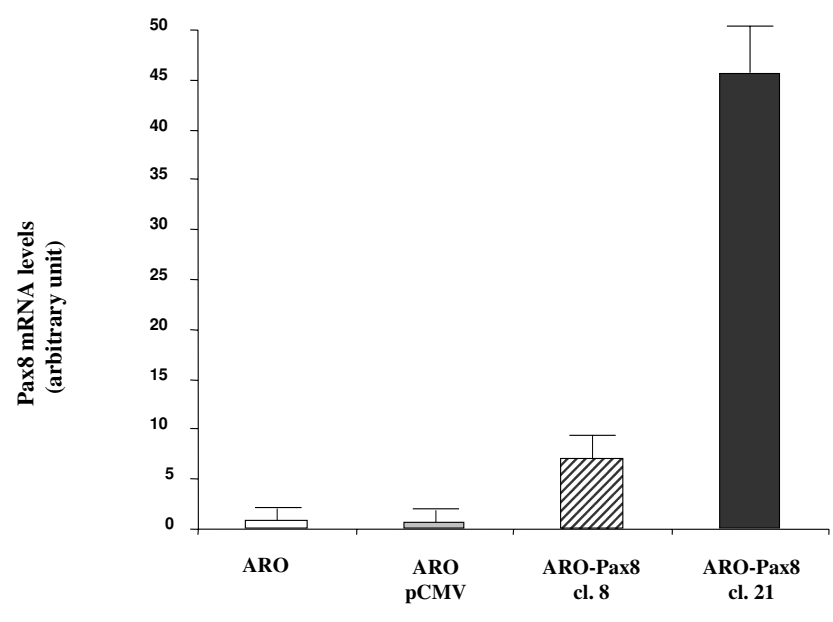

Figure I

Levels of expression of Pax8 mRNA in the wild-type and transfected ARO cells. ARO cells were transfected with a PCMV expression vector empty or containing the hPax8 gene, as described in Methods. Total RNA was extracted from duplicate dishes of wild-type ARO cells (ARO), cells containing the empty vector (ARO-pCMV) and two selected clones expressing Pax8 gene (ARO-Pax8 cl. 8 and ARO-Pax8 cl. 2 I (as described in Methods) and the levels of RNA were determined using the real-time PCR method. To normalize the different amount of total RNA added to the reaction, an amplification of GAPDH or $\beta$-actin was performed as endogenous control. The data are expressed as the mean \pm SD of values obtained from at least three different experiments. Statistic analysis was performed using the one-factor ANOVA, followed by $t$ test. $P<0.05$ was considered statistically significant.

Cells were harvested after 24, 48 and 72 hours and the number of cells was determined by Neubauer cell counting chamber.

\section{Results}

ARO cells were transfected with the pCMV-Script-hPax8 construct or the expression vector alone. A series of 24 clones were grown and screened for the presence of the insert (data not shown). Pax 8 mRNA levels were quantified by real time RT-PCR method and ARO-Pax 8 clones 8 and 21 were selected in that they overexpressed different amounts of Pax 8 transcript (Fig. 1).

Since Pax 8 has a key role in thyroid differentiation, we first checked in the ARO-Pax8 cells the presence of a series of thyroid specific genes. Fig. 2 shows the levels of the transcripts detected in the two clones versus wild-type ARO cells or ARO transfected with the empty vector (ARO-pCMV). The highest mRNA expression levels were

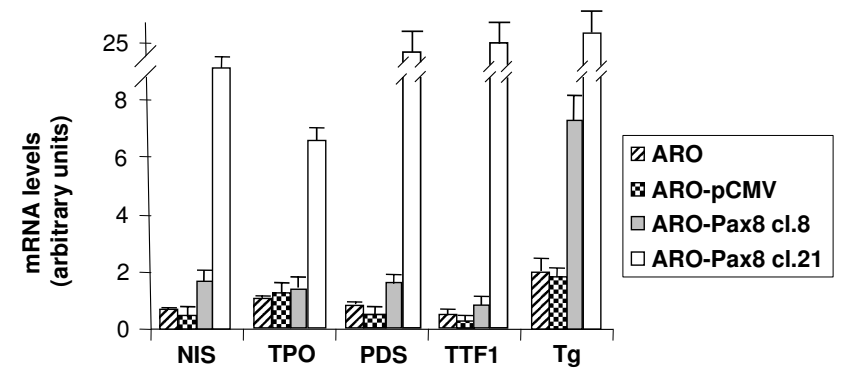

Figure 2

Levels of mRNA of various thyroid specific genes in wild-type and transfected ARO cells. Total RNA was extracted from duplicate dishes of wild-type ARO cells (ARO), cells containing the empty vector (ARO-pCMV), two selected clones expressing Pax8 gene (ARO-Pax8 cl. 8 and ARO-Pax8 cl. 2I) and the levels of RNA were determined using the real-time PCR method. To normalize the different amount of total RNA added to the reaction, an amplification of GAPDH or $\beta$-actin was performed as endogenous control. The data are expressed as the mean \pm SD of values obtained from at least three different experiments. Statistic analysis was performed using the one-factor ANOVA, followed by $t$ test. $P<0.05$ was considered statistically significant.

detected for Thyroglobulin gene (more than 20 fold in ARO-PAX8 clone 21), but also NIS, Pendrin, TPO and TTF1 gene were expressed in PAX8 clones with different levels of the transcripts depending on the different amount of Pax8 transcript (Fig. 2). All the transcript expression levels resulted lower (ranging between 10 and 100 fold) than those detectable in normal thyroid tissue (data not shown). The mRNA of the TSH receptor did not appear in the transfected cell clones (data not shown).

Goal of the study, however, was to verify the possibility to recover the ability to concentrate the radioiodine. For this reason we evaluated the NIS protein levels by Western blot analysis and its localization by immunofluorescence, together with the ability of ARO-Pax 8 cells to uptake the radioiodine. As shown in Fig. 3, NIS protein was detected in both clones and its amount paralleled that of the corresponding transcripts of NIS and Pax8. However, only few amount of the protein reached the plasmamembrane, as detected by immunofluorescence (Fig. 4). Accordingly, a low, but significant rate of radioiodine uptake reappeared in ARO-Pax8 cells with a similar pattern between the two 

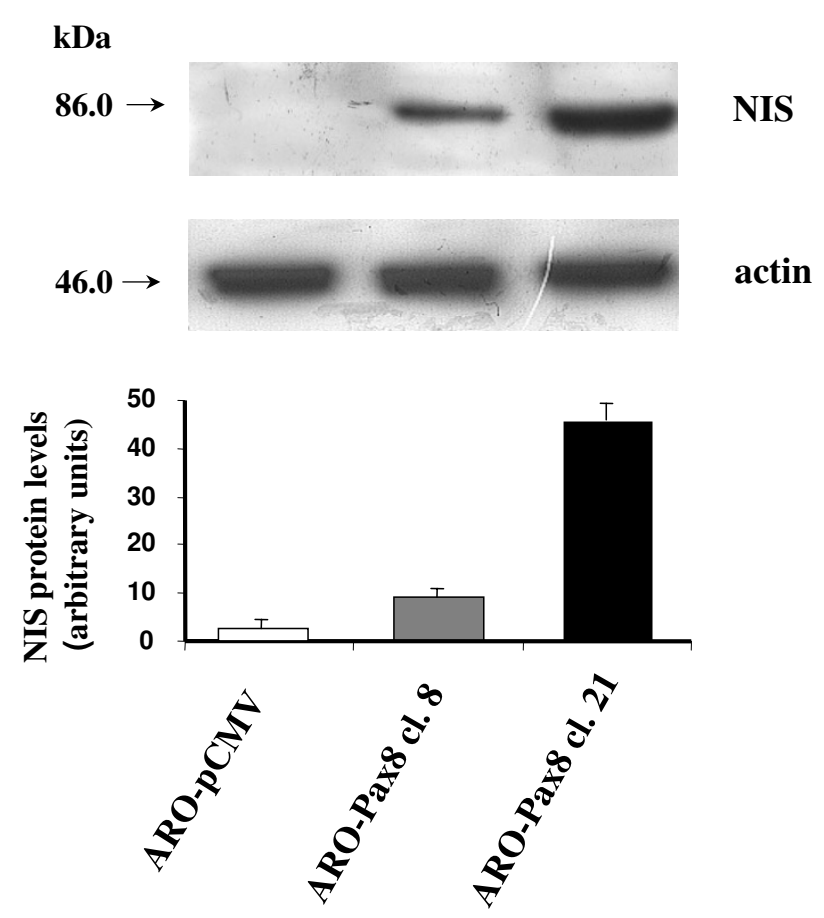

Figure 3

Expression of NIS protein in ARO cells expressing different levels of Pax8 gene. Western Blot analysis was performed as described in Methods. In upper panel/autoradiograph of a representative experiment. In lower panel/the staining intensity is expressed as mean \pm SD of values obtained from three different experiments. The data are expressed relative to the control values (cells transfected with the empty vector, ARO-pCMV). Statistic analysis was performed using the onefactor ANOVA, followed by $t$ test. $P<0.05$ was considered statistically significant.

clones and at much lesser extent than normal thyrocytes (Table 2). It was inhibited by perchlorate $(10 \mu \mathrm{M})$ (Table 2 ) and not stimulated by activation of the cAMP pathway obtained by incubating the cells with $10 \mu \mathrm{M}$ of Forskolin (data not shown). A high rate of efflux was also observed, at similar extent in both clones expressing Pax8 and earlier and much higher than that detected in FRTL-5 cells (Fig. $5)$.

Finally, in the ARO-Pax8 clones, we observed a lower growth rate in comparison to ARO non transfected cells (Fig. 6).

\section{Discussion}

A modified gene expression represents the basis for the development and acquisition of the abnormal growth and differentiation characteristics of tumour cells. Since the regulation of the gene expression takes place mainly at transcriptional level, structural or functional alterations of transcription factors, especially those specific for a given tissue, play a key role in the oncogenic process [18]. In thyroid cells, the simultaneous expression of a cohort of tissue-specific transcription factors, including TTF1, TTF2, Pax8 and HEX has been described [19]. Their expression and correct function is essential for the normal development of thyroid gland, and is often altered (reduced or lost) in thyroid tumours, especially in the poorly differentiated histotypes [11]. As a result, thyroid tumour cells present a dedifferentiated phenotype, including a reduced/lost ability to concentrate the radioiodine. This feature represents one of the major determinant of the poor prognosis of less differentiated thyroid carcinomas, since it does not allow the use of radioiodine as diagnostic and therapeutic tool for both tumour remnants or distant metastases. For this reason, attempts to reintroduce such a functional activity in tumour cells have represented the goal of many studies. The cloning and characterization of the protein responsible for iodide uptake, the NIS [20], has opened the way to novel therapeutic strategies based on induction of iodide uptake ability in tumour cells by recovery the expression of the NIS gene. Subsequently, a NIS-based gene therapy approach by using viral vectors has been exploited [4-7]: despite promising results obtained in both in vitro and in vivo experimental models, unresolved issues still remain before proposing such a treatment on humans, mainly a great efflux rate of the administered radioiodine which makes the effective dose of radioisotope (to be administered to destroy the tumour tissue) too high to be side effect free. A parallel approach to restore radioiodine uptake is to induce endogenous NIS expression and correct function by acting on its transcriptional regulation. Various molecules have been challenged, including retinoids, demethylating agents and inhibitors of histone deacetylation [21-25], with preliminary promising effects in various in vitro and in vivo experimental models. However, in poorly differentiated thyroid tumour cells, reexpression of NIS protein is not always accompanied by recovery of its function [26] and, at present, despite their unequivocal activity in vitro, retinoids did not show a sufficient effectiveness in clinical trials on human patients [27]. Probably, alterations of other proteins, including some involved in the intrathyroidal metabolism of iodine or in the correct folding, trafficking, polar localization and function of the NIS, do occur in tumour cells, making not fully effective the simple restoration of NIS expression.

In this work, we explored an alternative way to recover radioiodine concentration ability in thyroid tumour cells. Indeed, we tried to activate the transcriptional machinery which physiologically control NIS gene expression by acting on its promoter, as well as other thyroid specific gene 

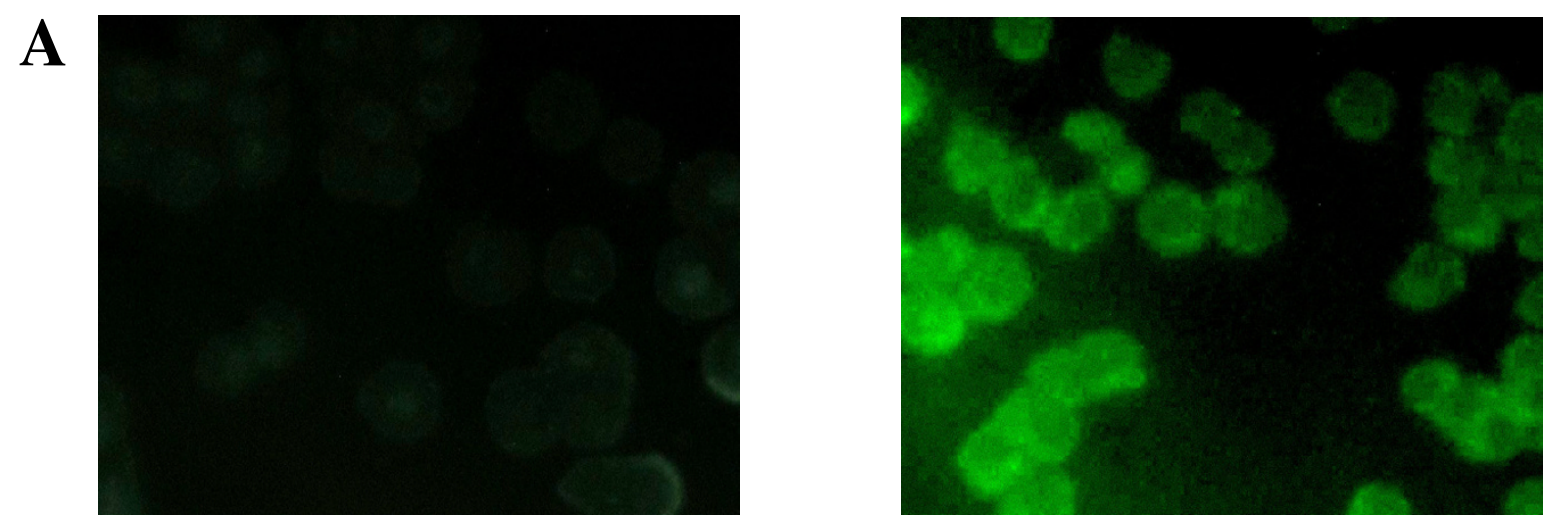

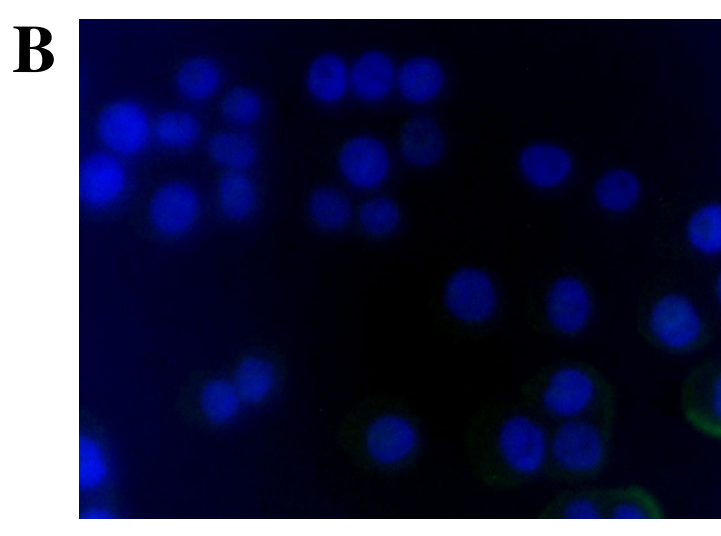

ARO-pCMV

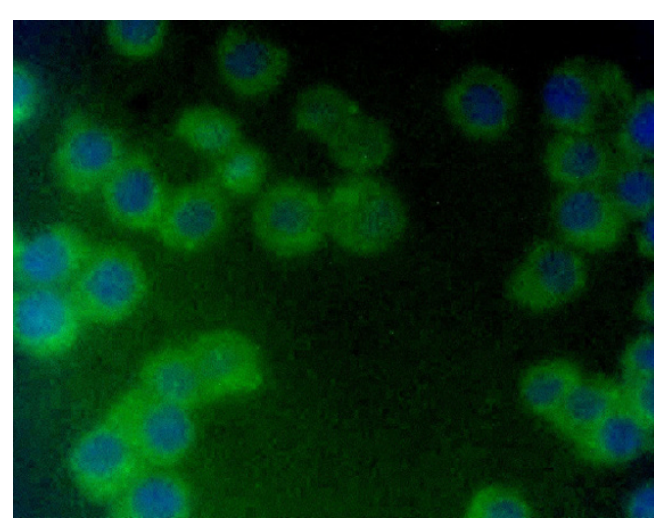

ARO-Pax8 cl. 21

\section{Figure 4}

Immunofluorescent localization of NIS in ARO cells. ARO-pCMV and ARO-Pax8 cl. $2 \mathrm{I}$ cells were analyzed by immunofluorescence microscopy using rabbit polyclonal anti-NIS and anti-rabbit FITC secondary antibody. A: NIS (green) localization; B. Double immunofluorescence with blue that indicates DAPI nuclear staining and green that indicates the NIS localization.

Magnification: $40 \times$.

cooperating to express the differentiated thyrocyte phenotype. On this regard, the paired domain-containing protein Pax8 has been characterized for its physiological role in the development of thyroid tissue and maintenance of thyrocyte differentiation phenotype [28,29]. Moreover, reduction/lost of Pax 8 expression has been described in thyroid tumour tissues and cell lines [[11], our unpublished observations]. Pax8-binding sites have been described in the promoters of human TPO, Thyroglobulin and recently, also NIS gene $[8,9]$. In addition, re-expression of Pax8 was associated with the recovery of the NIS, as well as TPO and Tg mRNA expression in a rat thyroid cell line [30]. An effect on Tg and TPO promoter activity had been previously described, in cooperation with TTF1 , also in human thyroid tumour cell lines [31].

Our study demonstrates that thyroid tumour cells expressing Pax8 after stable transfection become able to uptake the radioiodine, even if in absence of a full recovery of NIS protein expression on their plasmamembrane. In addition, other markers of thyroid differentiation were detectable after Pax8 expression, including proteins involved in the intrathyroidal metabolism of iodine such as TPO and pendrin. The expression levels of these thyroid-specific genes were strictly related to the amount of Pax8 expressed in the transfected clones, emphasizing the importance of the levels of this transcription factor for 

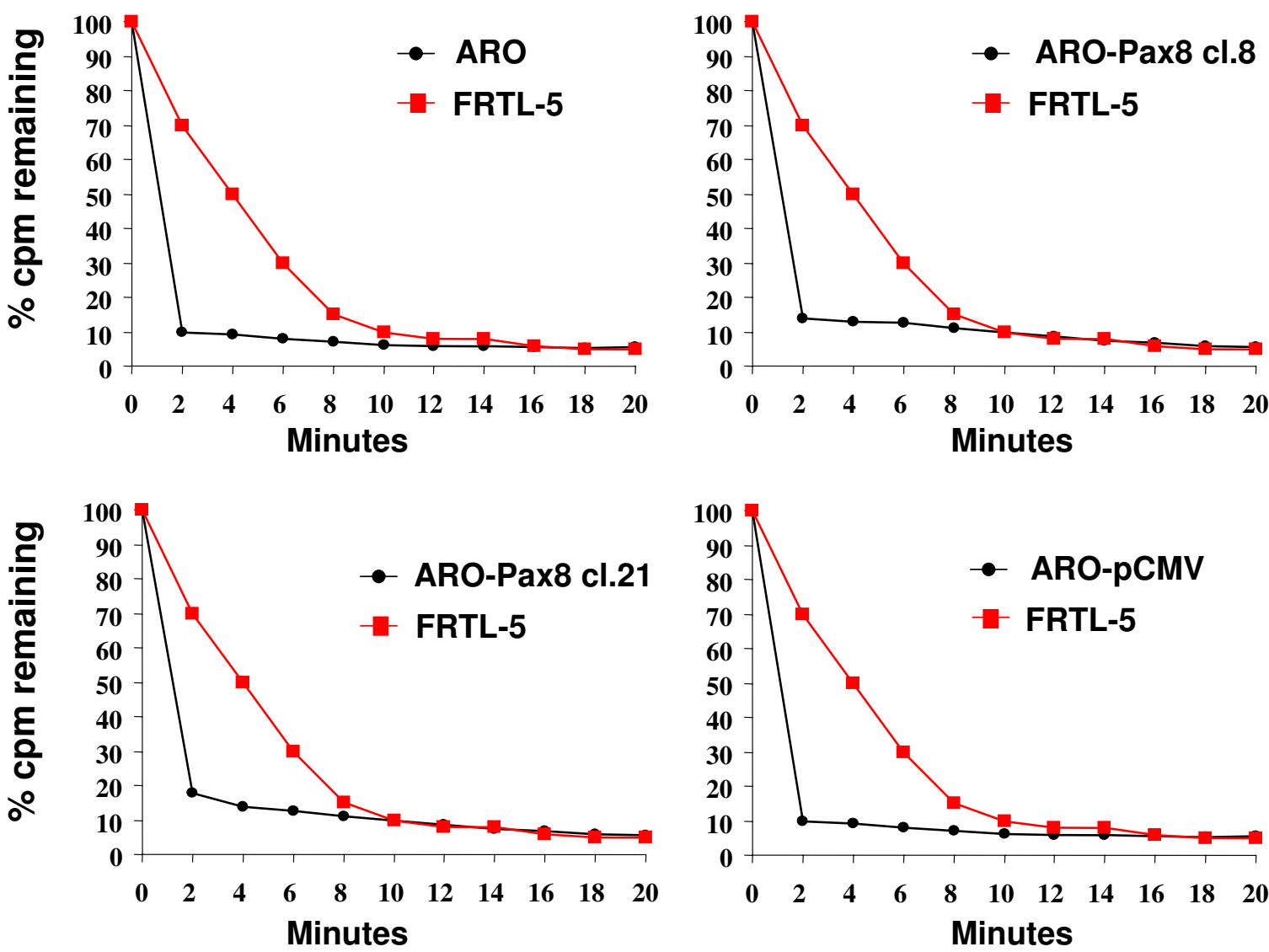

Figure 5

lodide efflux studies in wild-type and transfected ARO cells. Wild-type and transfected ARO cells (black circles) and FRTL-5 (red squares) grown to $95 \%$ confluency in $35-\mathrm{mm}$ diameter plates were incubated in shaking water bath for $60 \mathrm{~min}$ at $37^{\circ} \mathrm{C}$ in HBSS buffer containing $10 \mu \mathrm{M} \mathrm{Nal}$ and I $\mu \mathrm{C}$ 125. To evaluate the iodide efflux, the medium was removed and replaced with I $\mathrm{ml}$ of non-radioactive medium every $2 \mathrm{~min}$. After removal of the last medium $(20 \mathrm{~min})$ cells were extracted using I ml ethanol (see Methods). The values shown are the counts per min remaining (as percentage of the total) at the indicated times. The experiment has been performed two fold, being no differences in the obtained data.

determining a differentiated phenotype [32]. It is of interest also our finding of the recovery of TTF- 1 gene expression in the cells with higher levels of Pax8 which suggests a regulatory role for Pax 8 at TTF-1 gene promoter level. It may contribute to the phenotypical effects observed and confirms the existence of various levels of cooperation among tissue specific transcription factors [33]. On this regard, few data are available about TTF1 gene promoter, although previous experimental data had suggested the TTF1 gene as a candidate target for regulation by homeobox proteins [34].
However, Pax8 and TTF1 do not determine a full recovery of normal thyrocyte phenotype, as demonstrated by the presence of lower expression levels of the transcripts in comparison with normal thyroid tissue and the absence of detectable levels of the TSH receptor even in the clones overexpressing Pax8, and, more important, the low intracellular retention of radioiodide. In ARO cells, a greater efflux rate had been also observed after overexpression of exogenous NIS gene inserted in a viral vector [35]; similarly, only a faint iodide uptake reappeared in BHP18-21v thyroid tumour cells expressing TTF1 [36]. Moreover, contrasting results have been reported after stimulation of 
Table 2: Radioiodide uptake in wild-type and transfected ARO cells

\begin{tabular}{|c|c|c|c|c|}
\hline \multirow[t]{2}{*}{ Cell type } & \multicolumn{4}{|c|}{ lodide uptake (cpm/well) } \\
\hline & & $P$ & $+\mathrm{KClO}_{4}$ & $P$ \\
\hline ARO wild-type & $133 \pm 35$ & & $78 \pm 26$ & $* * 0.09$ \\
\hline ARO pCMV & $137 \pm 42$ & $* 0.9$ & $82 \pm 47$ & $* * 0.2$ \\
\hline ARO-PAX8 clone 8 & $307 \pm 43$ & $* 0.006$ & $126 \pm 27$ & $* * 0.003$ \\
\hline ARO-PAX8 clone 2I & $257 \pm 36$ & $* 0.01$ & $104 \pm 26$ & $* * 0.004$ \\
\hline FRTL-5 & $4350 \pm 320$ & & & \\
\hline $\mathrm{CHO}$ & $40 \pm 12$ & & & \\
\hline
\end{tabular}

lodide uptake was analyzed as described in Methods. The FRTL-5 cells and CHO cells were used as positive and negative controls, respectively. lodide uptake was expressed as the mean \pm SD of values obtained from three separate experiments. Statistic analysis was performed using the onefactor ANOVA, followed by $t$ test. $P<0.05$ was considered statistically significant.

* ARO PAX8 clone 8, clone 21 and ARO PCMV vs ARO wild-type;

** Uptake with vs Uptake without $\mathrm{KClO}_{4}$

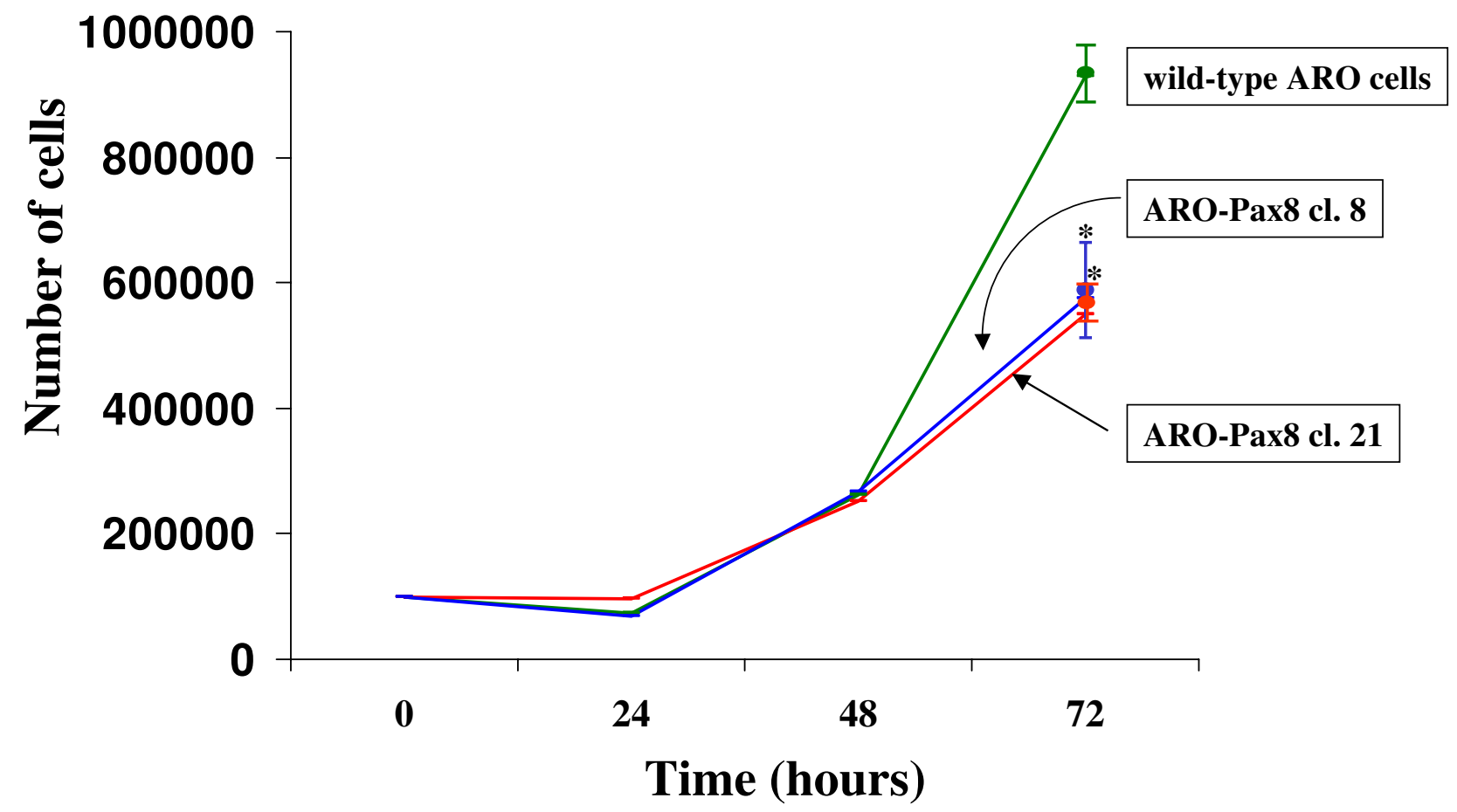

\section{Figure 6}

Growth rate of wild-type and transfected ARO cells. $10^{5}$ cells were plated in $60 \mathrm{~mm}$ dishes. Seven hours were considered as extra time needed from cells to sediment and start to proliferate. Cells were harvested after 24, 48 and 72 hours and the number of cells was determined by Neubauer cell counting chamber. ${ }^{*} \mathrm{p}$ value $<0.00 \mathrm{I}$ 
endogenous NIS expression by inhibition of histone deacetylation: by using valproic acid, Fortunati et al. [26] did not obtain a correct localization of the NIS protein in the thyrocyte plasmamembrane, whereas Furuya et al. [25] described a full recovery of iodide uptake also in ARO cells using the histone deacetylase inhibitor depsipeptide. In addition, our observation of the slower growth rate of ARO-Pax8 cells suggest a role for Pax8 in the control of such a function, until now never detected. Altogether, these data indicate that in addition to act on NIS transcription, a more complex strategy including the correct targeting to the plasmamembrane is required to reach the goal of an effective radioiodine intracellular concentration.

\section{Conclusion}

Our finding demonstrate that overexpression of thyroidspecific transcription factors may be a first step to obtain the radioiodine concentration by the transformed thyrocytes, by acting on a pool of differentiation markers including the NIS. Our data, therefore, represent a very promising starting point for further investigations and strategies exploiting this effect of Pax8, eventually in combination of other thyroid-specific transcription factors, for extending radioiodine treatment also to the less differentiated thyroid tumours.

\section{Competing interests}

The author(s) declare that they have not competing interests.

\section{Acknowledgements}

This work was granted by MIUR-Cofin 2003 to D. Russo, by Ministry of Health and MIUR-Cofin 2004 to Prof. S. Filetti. I. Presta was supported by a fellowship from AIRC/FIRC.

\section{References}

I. Schlumberger M: Papillary and follicular thyroid carcinoma. $N$ Engl J Med 1998, 338:297-306.

2. Sherman SI: Thyroid carcinoma. Lancet 2003, 36 I:501-5II.

3. Schlumberger M, Tubiana M, De Vathaire F, Hill C, Gardet P, Travagli JP, Fragu P, Lumbroso J, Caillou B, Parmentier C: Long-term results of treatment of 283 patients with lung and bone metastases from differentiated thyroid carcinoma. J Clin Endocrinol Metab 1986, 63:960-967.

4. Filetti S, Bidart JM, Arturi F, Caillou B, Russo D, Schlumberger M: Sodium/iodide symporter: a key transport system in thyroid cancer cell metabolism. Eur J Endocrinol 1999, I 41:443-457.

5. Spitzweg C, Harrington KJ, Pinke LA, Vile RG, Morris JC: The Sodium/iodide symporter and its potential role in cancer therapy. J Clin Endocrinol Metab 2001, 86:3327-3335.

6. Shen DHJ, Kloos RT, Mazzaferri EL, Jhiang SM: Sodium/iodide symporter in health and disease. Thyroid 200I, I I:4I5-425.

7. Dohan O, De la Vieja A, Paroder V, Riedel C, Artani M, Reed M, Ginter CS, Carrasco N: The sodium/iodide Symporter (NIS): characterization, regulation, and medical significance. Endocr Rev 2003, 24:48-77.

8. Schmitt TL, Espinoza CR, Loos U: Transcriptional regulation of the human sodium/iodide symporter gene by Pax8 and TTFI. Exp Clin Endocrinol Diabetes 200I, I 09:27-3I.

9. Taki K, Kogai T, Kanamoto Y, Hershman JM, Brent GA: A thyroidspecific far-upstream enhancer in the human sodium/iodide symporter gene requires $\mathrm{Pax}-8$ binding and cyclic adenosine 3',5'-monophosphate response element-like sequence bind- ing proteins for full activity and is differentially regulated in normal and thyroid cancer cells. Mol Endocrinol 2002, 1 6:2266-2282.

10. Puppin C, Arturi F, Ferretti E, Russo D, Sacco R, Tell G, Damante G, Filetti S: Transcriptional regulation of human NIS gene: a role for Redox factor-I. Endocrinology 2004, I 45: I 290-I 293.

II. Fabbro D, Di Loreto C, Beltrami CA, Belfiore A, Di Lauro R, Damante $G$ : Expression of thyroid-specific transcription factors TTF-I and PAX-8 in human thyroid neoplasms. Cancer Res 1994, 54:4744-4749.

12. Pang XP, Hershman JM, Chung M, Pekary AE: Characterization of tumor necrosis factor-alpha receptors in human and rat thyroid cells and regulation of the receptors by thyrotropin. Endocrinology 1989, I 25: I783-1788.

13. Puppin C, Presta I, D'Elia AV, Tell G, Arturi F, Russo D, Filetti S, Damante G: Functional interaction among thyroid-specific transcription factors: Pax8 regulates the activity of $\mathrm{Hex}$ promoter. Mol Cell Endocrinol 2004, 2 I 4: I I 7-I 25.

14. Arturi F, Lacroix L, Presta I, Scarpelli D, Caillou B, Schlumberger M, Russo D, Bidart JM, Filetti S: Regulation by human Chorionic Gonadotropin of Sodium/lodide symporter gene expression in the JAr human choriocarcinoma cell lines. Endocrinology 2002, I 43:2216-2220.

15. Arturi F, Russo D, Bidart JM, Scarpelli D, Schlumberger M, Filetti S: Expression pattern of the pendrin and sodium/iodide symporter (NIS) gene in human thyroid carcinoma cell lines and human thyroid tumors. Eur J Endocrinol 200I, I 45: I29-I35.

16. Russo D, Bulotta S, Bruno R, Arturi F, Giannasio P, Derwahl M, Bidart $J M$, Schlumberger M, Filetti S: Sodium/iodide symporter (NIS) and pendrin are expressed differently in hot and cold nodules of thyroid toxic multinodular goiter. Eur J Endocrinol 2001, | 45:59|-597.

17. Weiss SJ, Philp NJ, Grollman EF: lodide transport in a continuous line of cultured cells from rat thyroid. Endocrinology 1984, I | 4: 1090-1098.

18. Latchman DS: Transcription factor mutations and human disease. N Engl J Med 1996, 334:28-33.

19. Damante G, Tell G, Di Lauro R: A unique combination of transcription factors controls differentiation of thyroid cells. Prog Nucleic Acid Res Mol Biol 2001, 66:307-356.

20. Dai G, Levy O, Carrasco N: Cloning and characterization of the thyroid iodide transporter. Nature 1996, 379:458-460.

21. Schmutzler C, Winzer R, Meissner-Weigl J, Kohrle J: Retinoic acid increases sodium/iodide symporter mRNA levels in human thyroid cancer cell lines and suppresses expression of functional symporter in nontransformed FRTL-5 rat thyroid cells. Biochem Biophys Res Commun 1997, 240:832-838.

22. Venkataraman GM, Yatin M, Marcinek R, Ain KB: Restoration of iodide uptake in dedifferentiated thyroid carcinoma: relationship to human $\mathrm{Na}^{+} / \mathrm{l}-$ symporter gene methylation status. J Clin Endocrinol Metab 1999, 84:2449-2457.

23. Kitazono M, Robey R, Zhan Z, Sarlis NJ, Skarulis MC, Aikou T, Bates $\mathrm{S}$, Fojo $\mathrm{T}$ : Low concentrations of the histone deacetylase inhibitor, Depsipeptide (FR90 I228), increase expression of the $\mathrm{Na}^{+} / \mathrm{l}-$ symporter and iodine accumulation in poorly differentiated thyroid carcinoma cells. J Clin Endocrinol Metab 2000 , 86:3430-3435.

24. Zarnegar R, Brunaud L, Kanauchi H, Wong M, Fung M, Ginzinger D, Duh QY, Clark $\mathrm{OH}$ : Increasing the effectiveness of radioactive iodine therapy in the treatment of thyroid cancer using Trichostatin A, a histone deacetylase inhibitor. Surgery 2002, 136:984-990.

25. Furuya F, Shimura H, Suzuki H, Taki K, Ohta K, Haraguchi K, Onaya T, Endo T, Kobayashi T: Histone deacetylase inhibitors restore radioiodide uptake and retention in poorly differentiated and anaplastic thyroid cancer cells by expression of the sodium/iodide symporter thyroperoxidase and thyroglobulin. Endocrinology 2004, I 45:2865-2875.

26. Fortunati N, Catalano MG, Arena K, Brignardello E, Piovesan A, Boccuzzi G: Valproic acid induces the expression of the $\mathrm{Na}+/ /$ symporter and iodine uptake in poorly differentiated thyroid cancer cells. J Clin Endocrinol Metab 2004, 89:1006-1009.

27. Gruning T, Tiepolt C, Zophel K, Bredow J, Kropp J, Franke WG: Retinoic acid for redifferentiation of thyroid cancer - does it hold its promise? Eur J Endocrinol 2003, I 48:395-402. 
28. Plachov D, Chowdhury K, Walther C, Simon D, Guenet IL, Gruss P: Pax8, a murine paired box gene expressed in the developing excretory system and thyroid gland. Development 1990, I 1 0:643-65I.

29. Zannini M, Francis-Lang H, Plachov D, Di Lauro R: Pax-8, a paired domain-containing protein, binds to a sequence overlapping the recognition site of a homeodomain and activates transcription from two thyroid-specific promoters. Mol Cell Biol 1992, I 2:4230-424 I.

30. Pasca di Magliano M, Di Lauro R, Tannini M: PAX8 has a key role in thyroid cell differentiation. Proc Natl Acad Sci USA 2000 97(22 I): |3|44-|3|49.

31. Chun YS, Saji M, Geiger MA: Overexpression of TTF-I and PAX8 restores thyroglobulin gene promoter activity in ARO and WRO cell lines. Surgery 1998, | 24: I I00- I I 05.

32. Damante G: Thyroid defects due to Pax8 gene mutations. Eur J Endocrinol 1998, I39:563-566.

33. Puppin C, D'Elia AV, Pellizzari L, Russo D, Arturi F, Presta I, Filetti S, Bogue CW, Denson LA, Damante G: Thyroid-specific transcription factors control Hex promoter activity. Nucleic Acids Res 2003, 31: $1845-1852$

34. Guazzi S, Lonigro R, Pintonello L, Boncinelli E, Di Lauro R, Mavilio F: The thyroid transcription factor-I gene is a candidate target for regulation by Hox proteins. EMBO J 1994, 13:3339-3347.

35. Lee WW, Lee B, Kim SJ, Jin J, Moon DH, Lee H: Kinetics of iodide uptake and efflux in various human thyroid cancer cells by expressing sodium iodide symporter gene via a recombinant adenovirus. Oncol Rep 2003, 10:845-849.

36. Furuya F, Shimura H, Miyazaki A, Taki K, Ohta K, Haraguchi K, Onaya $\mathrm{T}$, Endo $\mathrm{T}$, Kobayashi T: Adenovirus-mediated transfer of thyroid transcription factor-I induces radioiodide organification and retention in thyroid cancer cells. Endocrinology 2004, I 45:5397-5405.

\section{Pre-publication history}

The pre-publication history for this paper can be accessed here:

http://www.biomedcentral.com/1471-2407/5/80/prepub

Publish with Bio Med Central and every scientist can read your work free of charge

"BioMed Central will be the most significant development for disseminating the results of biomedical research in our lifetime. "

Sir Paul Nurse, Cancer Research UK

Your research papers will be:

- available free of charge to the entire biomedical community

- peer reviewed and published immediately upon acceptance

- cited in PubMed and archived on PubMed Central

- yours - you keep the copyright 